\title{
Evaluation of the moisture sources in two extreme landfalling atmospheric river events using an Eulerian WRF tracers tool
}

\author{
Jorge Eiras-Barca ${ }^{1}$, Francina Dominguez ${ }^{2}$, Huancui $\mathrm{Hu}^{2}$, Daniel Garaboa-Paz ${ }^{1}$, and \\ Gonzalo Miguez-Macho ${ }^{1}$ \\ ${ }^{1}$ Non-Linear Physics Group, Universidade de Santiago de Compostela, Galicia, Spain \\ ${ }^{2}$ Department of Atmospheric Sciences, University of Illinois at Urbana-Champaign, Urbana-Champaign, IL, \\ USA
}

Correspondence: Jorge Eiras-Barca (jorge.eiras@usc.es, jorge.eiras.b@gmail.com)

Received: 16 June 2017 - Discussion started: 27 June 2017

Revised: 23 October 2017 - Accepted: 31 October 2017 - Published: 22 December 2017

\begin{abstract}
A new 3-D tracer tool is coupled to the WRF model to analyze the origin of the moisture in two extreme atmospheric river (AR) events: the so-called "Great Coastal Gale of 2007" in the Pacific Ocean and the "Great Storm of 1987" in the North Atlantic. Results show that between 80 and $90 \%$ of moisture advected by the ARs, and a high percentage of the total precipitation produced by the systems have a tropical origin. The tropical contribution to precipitation is in general above $50 \%$ and largely exceeds this value in the most affected areas. Local convergence transport is responsible for the remaining moisture and precipitation. The ratio of tropical moisture to total moisture is maximized as the cold front arrives on land. Vertical cross sections of the moisture content suggest that the maximum in tropical humidity does not necessarily coincide with the low-level jet (LLJ) of the extratropical cyclone. Instead, the amount of tropical humidity is maximized in the lowest atmospheric level in southern latitudes and can be located above, below or ahead of the LLJ in northern latitudes in both analyzed cases.
\end{abstract}

\section{Introduction}

Atmospheric rivers (hereafter, ARs) are long and narrow structures in the lower troposphere that carry large amounts of water vapor (Zhu and Newell, 1998). Guan and Waliser (2015) have estimated that ARs have a median length of about $3600 \mathrm{~km}$, a median length / width ratio of about 7 and a mean integrated vapor transport (IVT) of $370 \mathrm{~kg} \mathrm{~m}^{-1} \mathrm{~s}^{-1}$. ARs are associated with the pre-cold frontal region and the warm conveyor belt (WCB) of extratropical cyclones (Gimeno et al., 2016). The maximum moisture flux often occurs within the low-level jet (LLJ) located at around $1 \mathrm{~km}$ height along the cold frontal boundary, and for this reason ARs and the LLJ are sometimes identified with each other (Dettinger et al., 2015). However, to account for most of the high IVT and moisture content defining an AR, usually a wider region encompassing the layers below $2.5 \mathrm{~km}$ ahead of the cold front must be considered (Ralph et al., 2004, 2005). On occasion, the relationship between ARs and cyclones has been shown to be complex, with documented cases in which multiple cyclones are associated with a single AR (Sodemann and Stohl, 2013).

ARs supply moisture to the WCB of the cyclones and are therefore considered as one of the potential precursors of extreme precipitation, particularly when landfall occurs (e.g., Gimeno et al., 2016). The relationship between ARs and flood events has been extensively analyzed for the US West Coast region (e.g., Higgins et al., 2000; Ralph et al., 2005, 2006, 2004, 2013; Bao et al., 2006; Neiman et al., 2008a, b; Leung and Qian, 2009; Dettinger, 2011; Dettinger et al., 2011; Warner et al., 2012, 2014; Rutz et al., 2013; Kim et al., 2013), Europe (Lavers et al., 2011, 2012, 2013; Lavers and Villarini, 2013, 2014; Ramos et al., 2015, 2016; Eiras-Barca et al., 2016; Brands et al., 2016) and other regions world- 
wide (e.g., Mahoney et al., 2016; Mundhenk et al., 2016). It is important to better understand the physical mechanisms leading to extreme flooding associated with ARs, considering their impacts on human and natural systems and the mounting evidence that ARs are projected to become more frequent and intense in the future (e.g., Dettinger, 2011; Lavers et al., 2013; Payne and Magnusdottir, 2015).

Between three and five ARs can be found per hemisphere at any given time (Zhu and Newell, 1998), accounting for approximately $84 \%$ of the meridional IVT for the Northern Hemisphere and about $88 \%$ in the Southern Hemisphere (Guan and Waliser, 2015). Since these structures can transport an amount of precipitable water equivalent to several times the discharge of the Mississippi River (Ralph and Dettinger, 2011), ARs have been identified as a primary feature of the global water cycle.

There are several proposed methods of AR detection, most of which are based on thresholds of integrated water vapor (IWV) and/or IVT, shape criteria, and from satellite or reanalysis data (e.g., Ralph et al., 2004; Bao et al., 2006; Lavers et al., 2011, 2012; Dettinger, 2011; Nayak et al., 2014; Ramos et al., 2015; Eiras-Barca et al., 2016; Brands et al., 2016). Guan and Waliser (2015) developed a global detection method using filters of intensity, direction, geometry and coherence of the structures. More recently, Eiras-Barca et al. (2016) proposed a combined IVT and IWV variablethreshold detection algorithm, which operates both in summer and winter months. These objective detection criteria have shown that AR structures of IWV and IVT can extend from the tropics into midlatitudes; however, they do not provide information about the source and sink regions of AR water vapor.

Tropical moisture exports have been identified as a primary source of moisture for ARs in Europe and the US West Coast (Dettinger et al., 2015). AR structures link remote sources of moisture from the tropics to midlatitudes through long corridors of advection (e.g., Knippertz and Wernli, 2010; Sodemann and Stohl, 2013; Knippertz et al., 2013; Ryoo et al., 2015; Ramos et al., 2015). These studies have primarily used backward Lagrangian tools to evaluate the source-sink regions. However, moisture from midlatitudes (local sources) has also been identified as an important source of water vapor convergence in AR events (Dettinger et al., 2015). Ramos et al. (2016) used the FLEXible PARTicle dispersion model (FLEXPART) to show that both tropical and local sources of moisture are present in AR landfall events for different European latitudes.

Some authors argue that local sources are primarily responsible for the high water vapor content within the AR core (Bao et al., 2006; Cordeira et al., 2013; Dacre et al., 2014). By calculating the water vapor budget of 200 extratropical cyclones, Dacre et al. (2014) conclude that tropical moisture reaching the extratropics only contributes to mid-level moisture, above the boundary layer. Following this perspective, ARs can be thought of as the footprints left behind the cyclone pathway, and not as a conduit for meridional transport of water vapor and latent heat. One possible explanation for the lack of agreement may be the sensitivity to the physics and parametrization schemes used in the latter analysis (Brands et al., 2016). The current understanding is that tropical moisture exports can provide a significant amount of moisture to ARs. Most of them also incorporate midlatitude sources of vapor along their path (Dettinger et al., 2015).

Considering that there is still an important discussion related to the origin of moisture in ARs, in this paper, we use a new forward moisture tracer tool coupled to the Weather Research and Forecast (WRF) model (Miguez-Macho et al., 2013; Dominguez et al., 2016; Insua-Costa and MiguezMacho, 2017) to evaluate the moisture sources of two particularly extreme AR case studies, as well as the transport mechanism of this humidity. The selected cases were associated with extreme precipitation and flooding that led to significant socioeconomic impacts. The first selected AR developed over the Pacific Ocean and affected the western coast of North America, whereas the second AR developed over the Atlantic Ocean and impacted the western coast of the Iberian Peninsula. The tracer tool allows us to track the tropical moisture associated with these two events and evaluate the relative contribution of this tropical moisture to total moisture and precipitation. In addition, the WRF tracer tool also provides information about the vertical distribution of tropical moisture, as well as the position of the maximum of moisture with regard to the LLJ.

\section{Data and methods}

\subsection{Data}

Both events were very intense in terms of IVT and IWV and are well detected by different methods (Guan and Waliser, 2015; Eiras-Barca et al., 2016; Brands et al., 2016). The first AR occurred on December 2007, affecting mostly the Pacific Northwest region of the United States (Fig. 1a-d). Locally known as the "Great Coastal Gale of 2007", this event primarily impacted the western state of Washington, and the associated flooding resulted in approximately USD 680 million direct losses from three severely impacted counties in the state (Avelino and Dall'erba, 2016; Dominguez et al., 2017) and 11 fatalities (NOAA, 2008). Formed from the remnants of the two typhoons Hagibis and Mitag, the event produced hurricane force winds (Crout et al., 2008). The rapid and explosive development of the cyclone (the central pressure fell more than $24 \cdot \sin \varphi / \sin \left(60^{\circ}\right) \mathrm{hPa}$ in $24 \mathrm{~h}$, where $\varphi$ is the given latitude) is shown in Figs. 1a-d and A1 in Appendix A. The selected AR case was the third and most intense of a series of three storms and led to extreme precipitation (NOAA, 2008). The landfalling event and the resulting precipitation is shown in Figs. 1d and 2d, respectively.

The episode developed from the merging of a cold front, already undergoing wave development, and a faster moving 

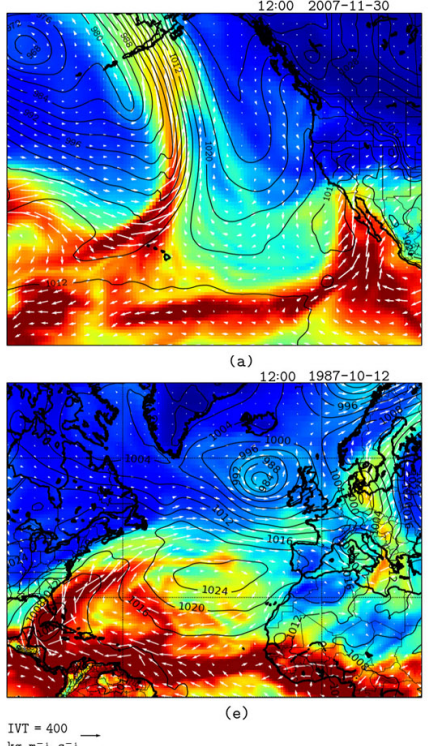

$\underset{\mathrm{IVT}}{\mathrm{IVI} \mathrm{m}^{-1} \mathrm{~s}^{-1}} \rightarrow$
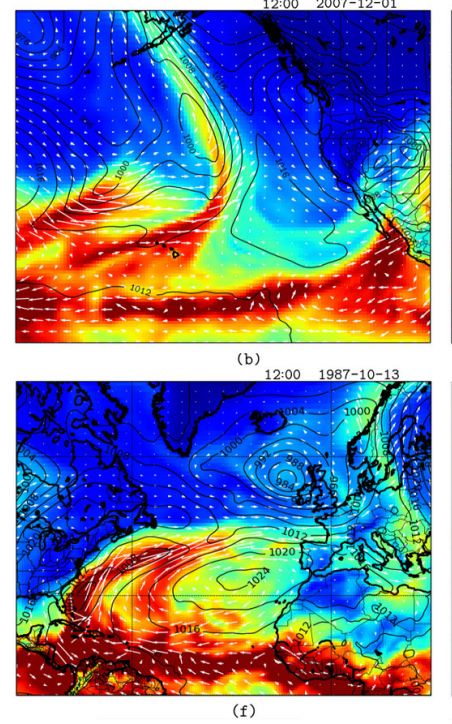

IWV $\left(\mathrm{kg} \mathrm{m}^{-}\right)$

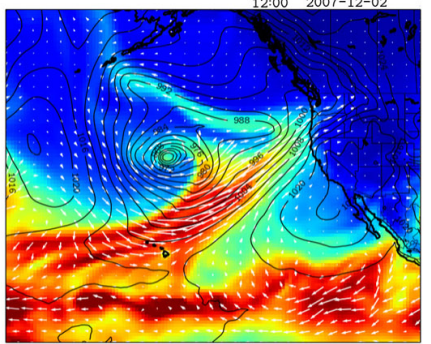

(c)

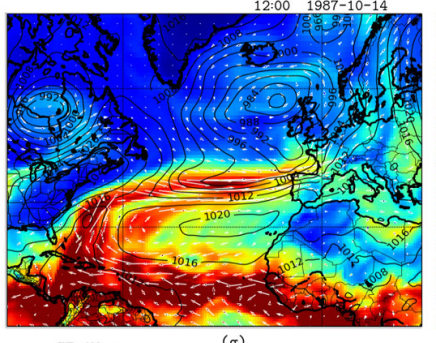

(g)

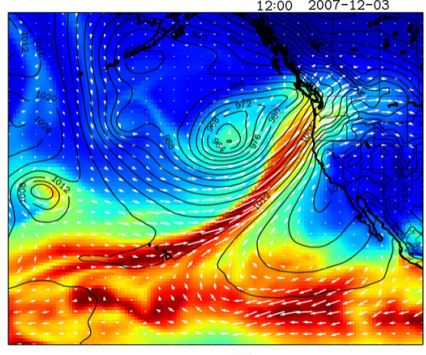

(d)

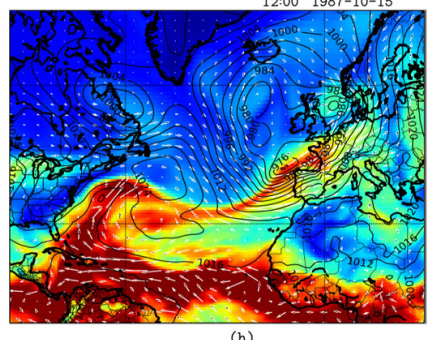

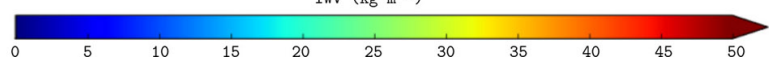

Figure 1. Integrated vapor transport (IVT, vectors, $\mathrm{kg} \mathrm{m}^{-1} \mathrm{~s}^{-1}$ ), sea level pressure (isobars, hPa) and integrated water vapor (IWV, background, $\mathrm{kg} \mathrm{m}^{-2}$ ) fields for both the Great Coastal Gale of 2007 (a-d) and the Great Storm of 1987 (e-h) events throughout a 4-day time frame. Source: ERA-Interim.

low pressure system catching up from behind. Both systems originated from typhoons and already had a high water vapor content. The interaction between the two resulted in an instant occlusion-like mechanism that led to the rapid deepening of the combined cyclone over the Pacific.

Figure $1 \mathrm{~h}$ shows the explosive cyclogenesis for the European event. In this case, there is also a complex development process, with the interaction between the remnants of a tropical system with high water vapor content and a wave on the long frontal boundary across the North Atlantic as a precursor of the explosive cyclogenesis occurring northwest of the Iberian Peninsula (see Fig. A2 in Appendix A).

The water vapor signature of the second case, which developed during October 1987, extended from the western tropical Atlantic Ocean to the Iberian Peninsula and British Isles. This event is the well-known "Great Storm of 1987", with reported losses of millions of pounds and 18 fatalities over the British Isles (e.g., Burt and Mansfield, 1988). For this case, Shutts (1990) showed that two-thirds of the central pressure falling could be ascribed to latent heat release, which suggests that the AR played a key role in the fast deepening of the cyclone ( $35 \mathrm{hPa}$ of pressure drop in $24 \mathrm{~h}$ ) (Fig. 1f-h). Figure A1 in Appendix A shows how the cooperative linkage between a trough in the tropopause and low-level baroclinicity contributed to the rapid growth of the system as well (Hoskins and Berrisford, 1988). The resulting precipitation (Fig. 2b) was reported at above $100 \mathrm{~mm}$ throughout the Spanish region of Galicia, shown in Fig. $2 b$.

\subsection{The Eulerian tracer tool}

The Eulerian tracer model is based on coupling a moisture tagging technique with the WRF meteorological model. The strategy consists in replicating the prognostic equations for the different moisture species with equations for moisture tracers. A moisture tracer in this context is defined as moisture originating from a predetermined source. The set of equations for tracers is solved coupled to the model's governing equations, meaning that tracers undergo turbulent diffusion with the same eddy diffusivities as their full moisture counterparts, and that convection and microphysics processes for tracers mimic those for full moisture, with the assumption that phase changes among the different tracer species occur in amounts proportional to the tracer fraction in the species undergoing the change. The tracer tool running coupled to the model can separate moisture from different sources with a very small error (less than $1 \%$ in traceability). Thus, the tracer tool is very accurate in the model world, while the uncertainty in the real word is due to the WRF model error. A more in-depth description of the Eulerian tracer tool and validation results can be found in InsuaCosta and Miguez-Macho (2017).

The Eulerian tracer tool operates as follows: a wide region in the domain covering the tropical latitudes is set up as a three-dimensional tracer mask. All the water vapor in this three-dimensional volume (including the water vapor evaporated and advected into the mask region) is tracked in space and time. Notably, while previous moisture tracer configurations in WRF focused on tracking water that evap- 


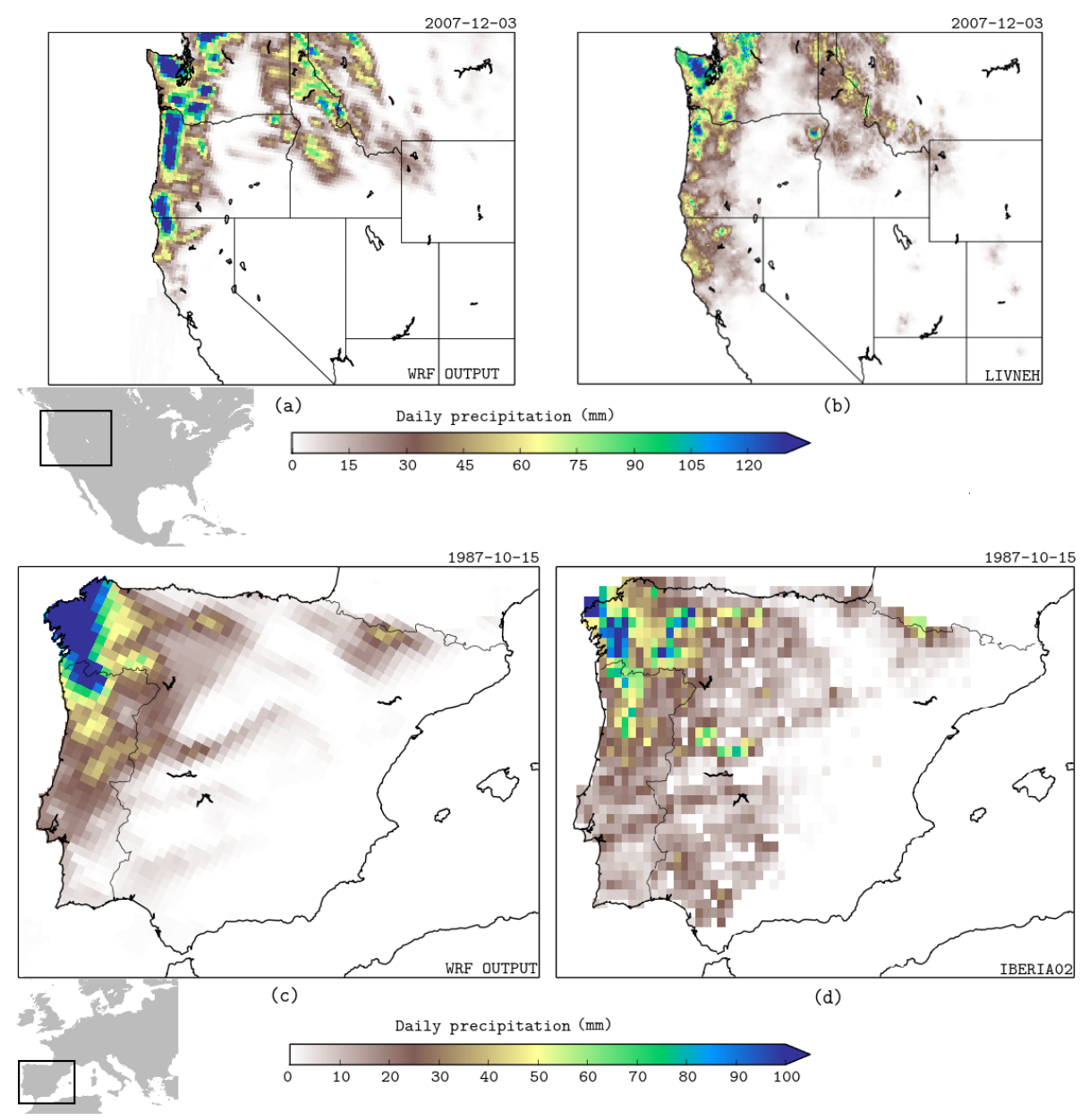

Figure 2. WRF output total precipitation for the Great Coastal Gale of 2007 (a) and the Great Storm of 1987 (c) against observations from LIVNEH (b) and IBERIA02 (d) for the same $24 \mathrm{~h}$ period.

orated from a two-dimensional region at the surface (e.g., Dominguez et al., 2016; Arnault et al., 2016), in this study all the moisture in a three-dimensional volume (including the water vapor evaporated and advected into the masked region) is tracked in space and time. For details, see Insua-Costa and Miguez-Macho (2017). Figure 3 shows the masks labeled in red for the Pacific (panel a) and Atlantic (panel b) simulations. Once the simulation starts, the model tracks the humidity originating from within the mask at any time, and the quantity of this moisture is known in relation to the total moisture content at each point of the domain, throughout the entire simulation. Similar to the rest of the moisture, the "tagged" water vapor can change phase, and the fraction of the condensed phase to the total condensate is also reported in the model output.

\subsection{WRF simulations setup}

We use WRF 3.4.1 to simulate these two events. For the Pacific case, the WRF horizontal resolution is $15 \mathrm{~km}$ and the vertical column is divided into 40 levels. For the At- lantic simulation, grid spacing is $20 \mathrm{~km}$ in the horizontal and there are 50 vertical levels. Both simulations cover a period of 10 days, from 26 November 2007 in the Pacific case and from 8 October 1987 in the Atlantic simulation. The moisture tracer tool is implemented in the Yonssei University (YSU) planetary boundary layer parameterization (Hong et al., 2006; Shin and Hong, 2011; Hu et al., 2010, 2013), the Kain-Fritsch convection scheme (Kain, 2004) and the WRF Single-Moment 6-Class Microphysics Scheme (WSM6) (Hong and Lim, 2006), which are the parametrizations employed in the simulations. In addition, the Rapid Radiative Transfer Model (RRTM) (Mlawer et al., 1997) and Dudhia (Dudhia, 1989) schemes were used for long-wave and shortwave radiation, respectively. Spectral nudging of waves above the boundary layer, longer than $1000 \mathrm{~km}$, with a relaxation timescale of $1 \mathrm{~h}$, is applied to avoid distortion of the large-scale circulation within the regional model domain due to the interaction between the model's solution and the lateral boundary conditions (Miguez-Macho et al., 2004, 2005). Further descriptions about WRF can be found in Ska- 


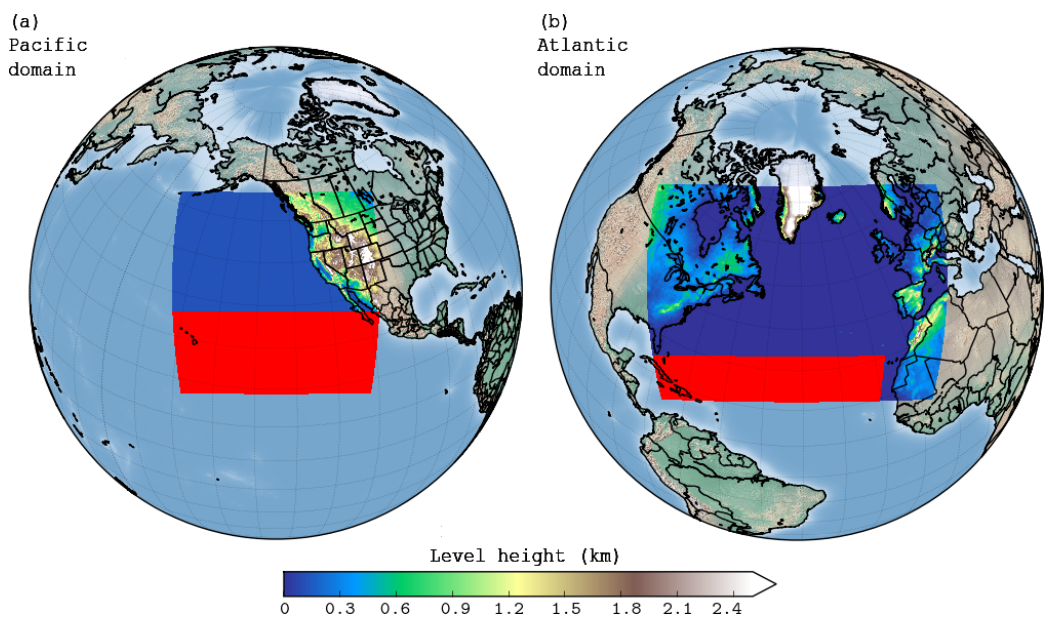

Figure 3. Domains of the WRF simulation (blue) for the Great Coastal Gale of 2007 (a) and the Great Storm of 1987 (b). Areas highlighted in red correspond to the masked region where the moisture is initially labeled as tracer.

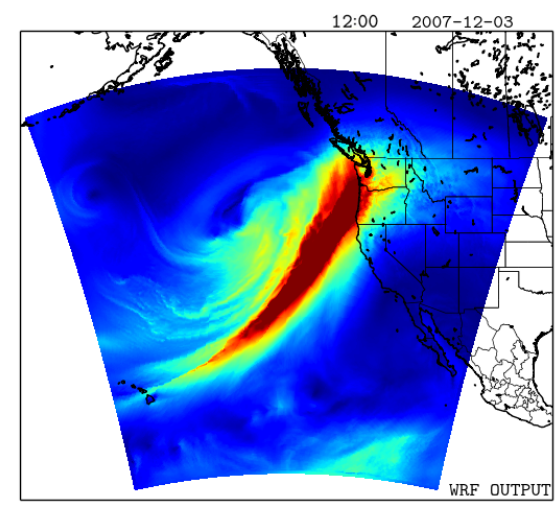

(a)

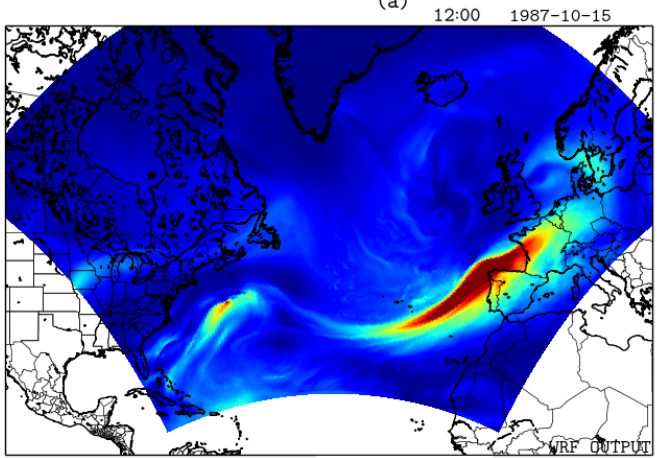

(c)

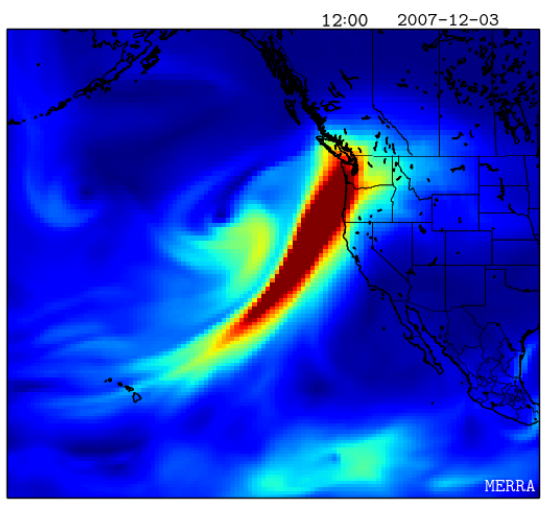

(b)

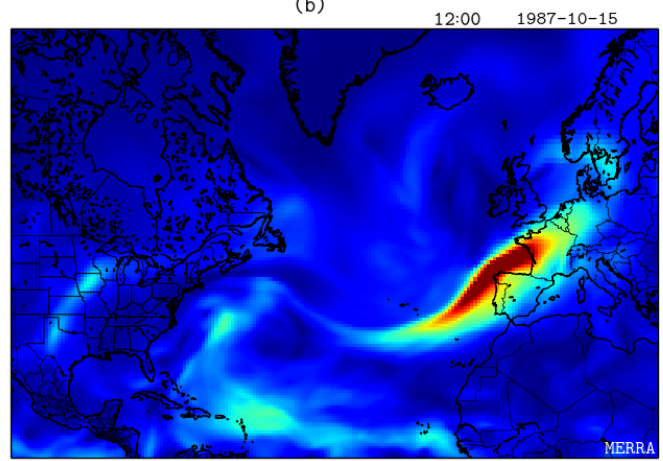

(d)

IVT $\left(\mathrm{kg} \mathrm{m}^{-1} \mathrm{~s}^{-1}\right)$

Figure 4. Absolute value of IVT in kilograms per meter per second for the Pacific event from WRF (a) and MERRA (b) as well as for the Atlantic event from WRF (c) and MERRA (d).

marock et al. (2005) or Michalakes et al. (2005). Finally, considering that the ECMWF reanalysis (ERA-Interim) has been shown to be a reliable tool in the analysis of ARs (Rutz et al., 2014), the dataset provides lateral boundary and initial conditions for the runs.
Since spectral nudging has been used in the simulations, the large-scale circulation in the model closely follows ERAInterim and no further validation is required (Gómez and Miguez-Macho, 2017). Water vapor is not nudged to ensure the mass conservation needed for the traceability of humidity 


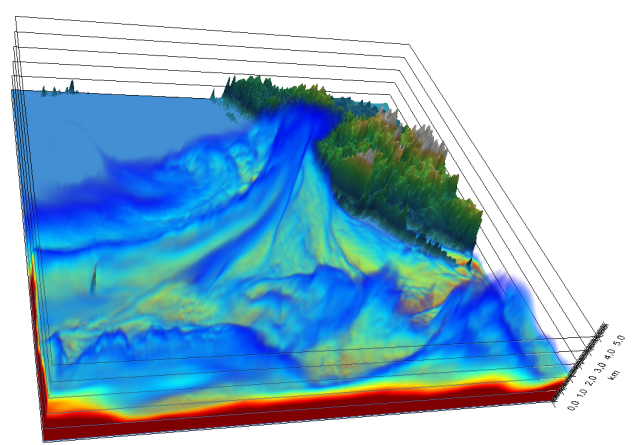

(a)

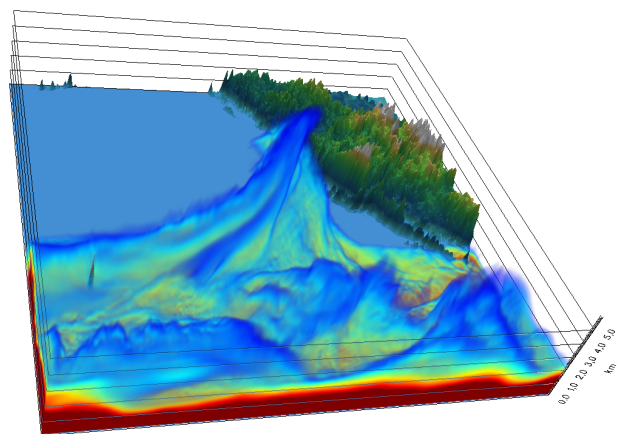

(b)

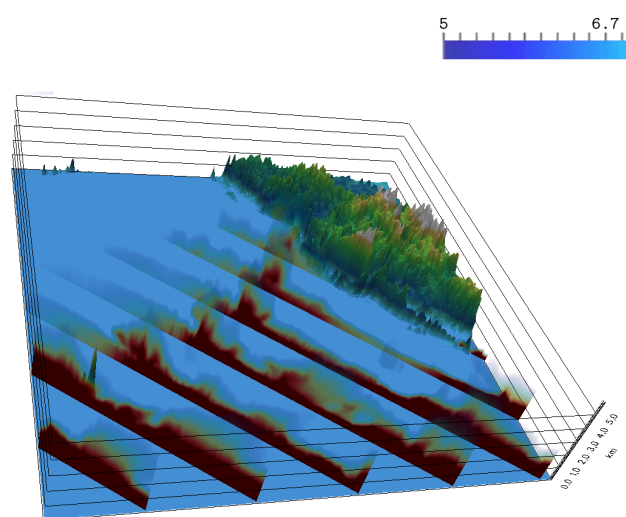

(c) $\left(\mathrm{g} \mathrm{kg}^{-1}\right.$ )
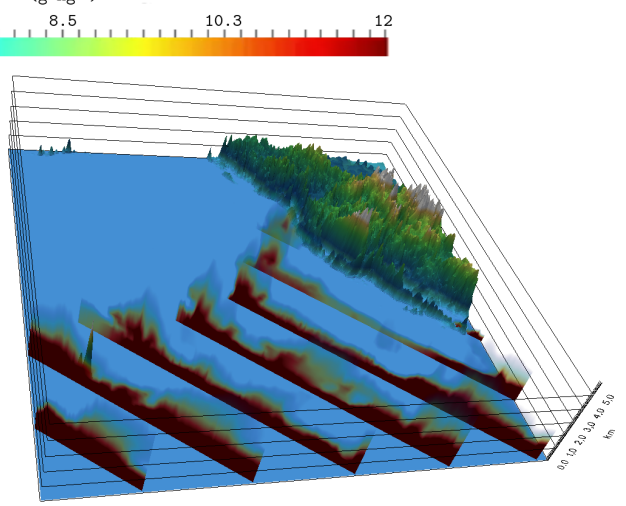

(d)
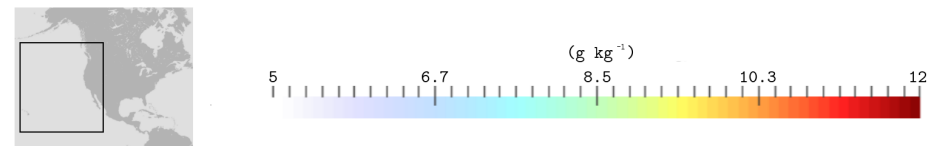

Figure 5. (a) Total water vapor mixing ratio in grams per kilogram at 3 December 2007 12:00 UTC for the Pacific domain. (b) Tracers water vapor mixing ratio in grams per kilogram at the same time and domain. (c) Vertical cross sections of (a). (d) Vertical cross sections of (b).

from different sources. Given that the subject of this study is moisture transport and precipitation, we focus validations on these two variables.

Finally, the integrated column of water vapor, and the integrated column of water vapor tracers $\left(\mathrm{IWV}_{\mathrm{TR}}\right)$ can both be calculated from the WRF simulations using Eqs. (2) and (3), respectively, where $q$ is the specific humidity, $g$ is gravity, $u$ and $v$ represent the wind fields, sfc is the land surface, and $l$ is the highest model level, well above the tropopause. The conversion between specific humidity $(q)$ and mixing ratio $(w)$ has been performed using Eq. (4).

$$
\begin{aligned}
& \mathrm{IVT}=\left|\frac{1}{g} \int_{\mathrm{sfc}}^{l} q \boldsymbol{u} \mathrm{d} p\right| \\
& \mathrm{IWV}=\frac{1}{g} \int_{\mathrm{sfc}}^{l} q \mathrm{~d} p
\end{aligned}
$$

$$
\begin{aligned}
& \mathrm{IWV}_{\mathrm{TR}}=\frac{1}{g} \int_{\text {sfc }}^{l} q_{\mathrm{TR}} \mathrm{d} p \\
& q=\frac{w}{w+1}, \text { with } w \ll 1 \Rightarrow q \approx w \\
& \boldsymbol{u}=(u, v)
\end{aligned}
$$

\section{Results and discussion}

Figure 2 shows the comparison between WRF-simulated and observed precipitation. Observations are from the Livneh et al. (2015) dataset for the Pacific simulation and from the Iberia02 precipitation dataset in the case of the Atlantic simulation. The latter dataset is a combination of Spain02 (Herrera et al., 2012) and Portugal02 (Belo-Pereira et al., 2011), both of which include a high density of good-quality stations (Herrera et al., 2012). Further comparison of the simulations with observations, against IWV (IVT, Eq. 1) from NASA's Modern-Era Retrospective Analysis for Research and Ap- 

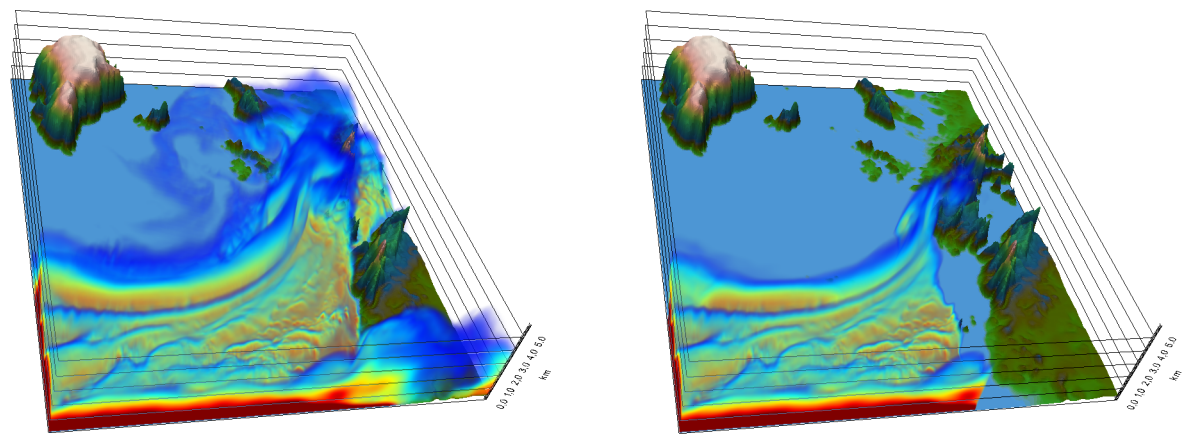

(a)

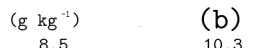

10.3

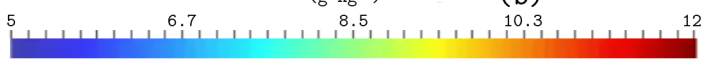

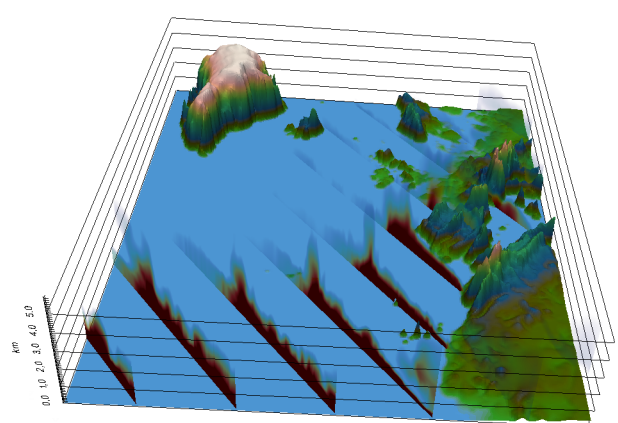

(c)

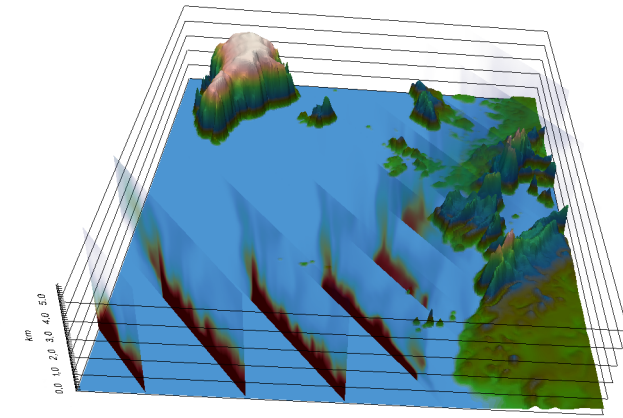

(d)
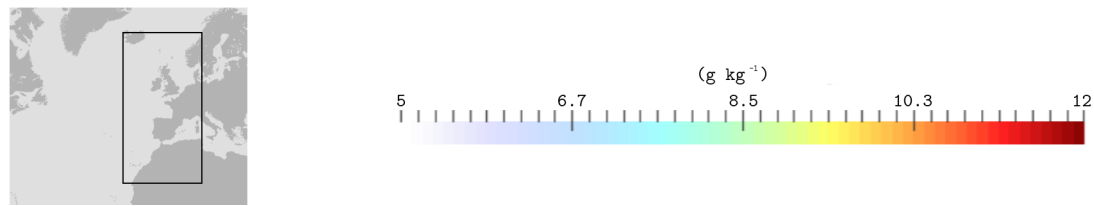

Figure 6. Same as Fig. 5 but for the European domain in the Great Storm of 1987 (15 October 1987 at 12:00 UTC).

plications (MERRA) (Rienecker et al., 2011) is provided in Fig. 4.

Whereas the simulated IVT field is realistic when compared to observations, WRF tends to overestimate precipitation. The overestimation is particularly high in the mountains of Oregon and Washington for the 2007 event. However, despite the fact that precipitation is arguably the most difficult variable to simulate in a numerical model (e.g., Maraun et al., 2010; Buckley and Marshall, 2016), the spatial pattern of precipitation is realistically represented.

Figure 5 shows the three-dimensional distribution of water vapor mixing ratio (panel a), and tracer water vapor mixing ratio (panel b) for the event in the Pacific that made landfall along the US West Coast. While the former accounts for the total amount of moisture, the latter shows only the moisture originating from tropical latitudes, labeled with the 3-D mask depicted in Fig. 3. The simulation was started 8 days before the time shown in Fig. 5. Panels (c) and (d) show a snapshot of the water vapor mixing ratio and the tracer water vapor mixing ratio in the form of a series of cross-section slices that allow the visualization of the vertical distribution of moisture. The images suggest that the vast majority of the moisture contained in the pre-frontal region has its origin in the tropical regions. This is especially true at lower latitudes. The maximum content of tropical moisture remains mostly in the lower levels. The high moisture values behind the front and at the leading edge of the AR structure, where the WCB is located, are not related to tropical advection and are thus generated by convergence of moisture from local sources occurring along the frontal region. Slightly different conclusions are obtained for the Atlantic case study shown in Fig. 6. For the sake of simplicity, only the eastern longitudes of the domain of simulation are shown. Even though the tropical moisture still remains in the lowest levels of the troposphere, its contribution to the total is less significant than for the Pacific case study. The reason is shown in Fig. 1e-h, indicating that most of the connection of the WCB with tropical regions is through a much longer path, due to the blocking position of the Azores High.

Figure 7a shows the percentage of IWV that comes from the tropics $\left(\mathrm{IWV}_{\mathrm{TR}} / \mathrm{IWV}\right)$ for the Pacific event. In a region extending from the tropics to the coast of Washington state, tropical moisture accounts for about $80-90 \%$ of the precipitable water and locally exceeding this contribution. 


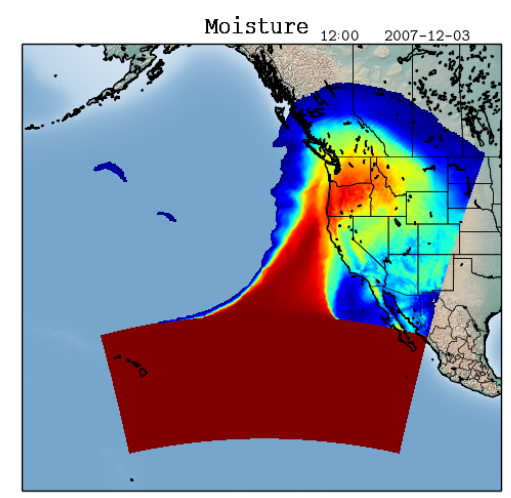

(a)

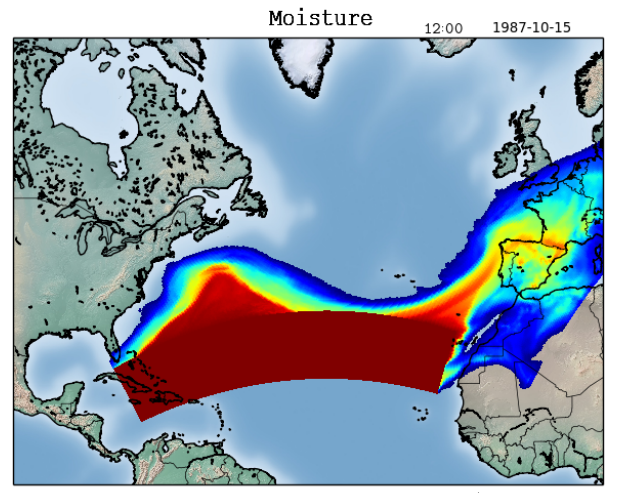

(c)

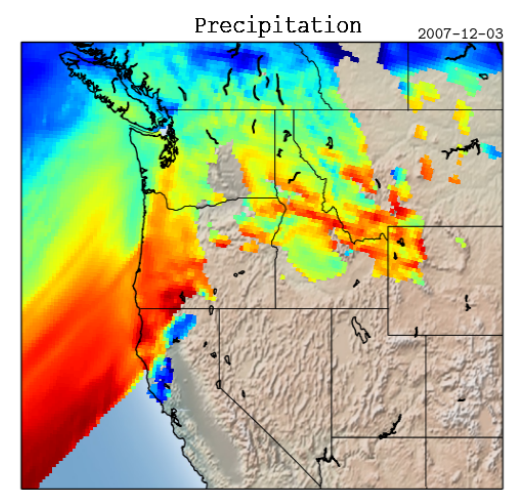

(b)

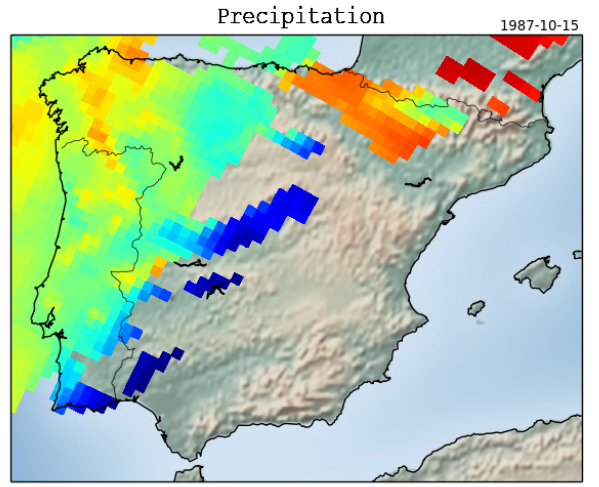

(d)

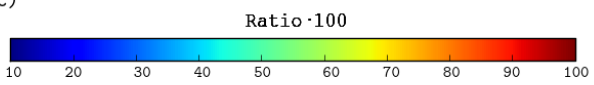

Figure 7. (a) Ratio of tagged water vapor to total water vapor for the Pacific event. (b) Same as (a) but for precipitation. Panels (c, d) are equivalent to (a, b), respectively, but for the Atlantic event.

These high percentages extend inland along the northwestern US coastal regions. Likewise, Fig. $7 \mathrm{~b}$ shows the $24 \mathrm{~h}$ accumulated percentage of precipitation that is composed of condensed tropical water vapor $\left(\mathrm{Prec}_{\mathrm{TR}} / \mathrm{Prec}\right)$. For clarity, we only plot the region where precipitation exceeded $3 \mathrm{~mm} \mathrm{day}^{-1}$ (Buishand, 1978). Precipitation of tropical origin accounts for 70 to $90 \%$ of total precipitation from northern California to southern Oregon, and the ratio decreases at higher latitudes. Interestingly, tropical moisture is funneled by local topography, and it contributes to about 70 to $80 \%$ of precipitation west of the Cascade Range. In the Atlantic case, we also see a clear plume where tropical water vapor accounts for more than $80 \%$ of precipitable water; however, the percentage decreases to around $70 \%$ close to the center of the system and just before arriving on the Iberian coast (Fig. 7c-d). In this case, cyclogenesis occurs just off the coast of Galicia, on the northwestern tip of the Iberian Peninsula, and thus the enhanced convergence of the existent local moisture feeds the AR and is involved in the heavy precipitation, which consequently is only between 60 and $80 \%$ of tropical origin. The high ratios observed in mountainous ranges such as the Pyrenees and the Rockies, far ahead of the cold front and the AR associated with the systems, are very likely due to the slantwise lift of tropical moisture in mid-levels along the warm frontal boundary.

Figure 8 plots a range of transversal cross sections showing the vertical distribution of the tracer water vapor mixing ratio through the central axis of the AR, as well as wind speed. From these results, there is evidence that the maximum of tropical moisture does not necessarily coincide with the LLJ, which is the maximum in wind speed at lower levels. More precisely, at the root of the AR, at subtropical latitudes (Fig. 8d), most of the tropical moisture remains close to the surface and below the LLJ, which can be identified at a height of $1 \mathrm{~km}$. As the central axis of the LLJ goes upward with latitude, tropical moisture tends to ascend in the vertical column, but the maximum of moisture can be located in front of or behind the LLJ, as well as remaining near the surface levels. In the leading part of the AR, the interaction of the humidity with the topography of the Pacific coast of North America makes the situation more difficult to analyze. Very likely, the complex formation process of the cyclone, from the interaction of two preexistent frontal systems, loaded with tropical moisture, adds complication to the thermodynamic structure and moisture distribution of the resulting front. Notwithstanding, this AR event is a particularly 

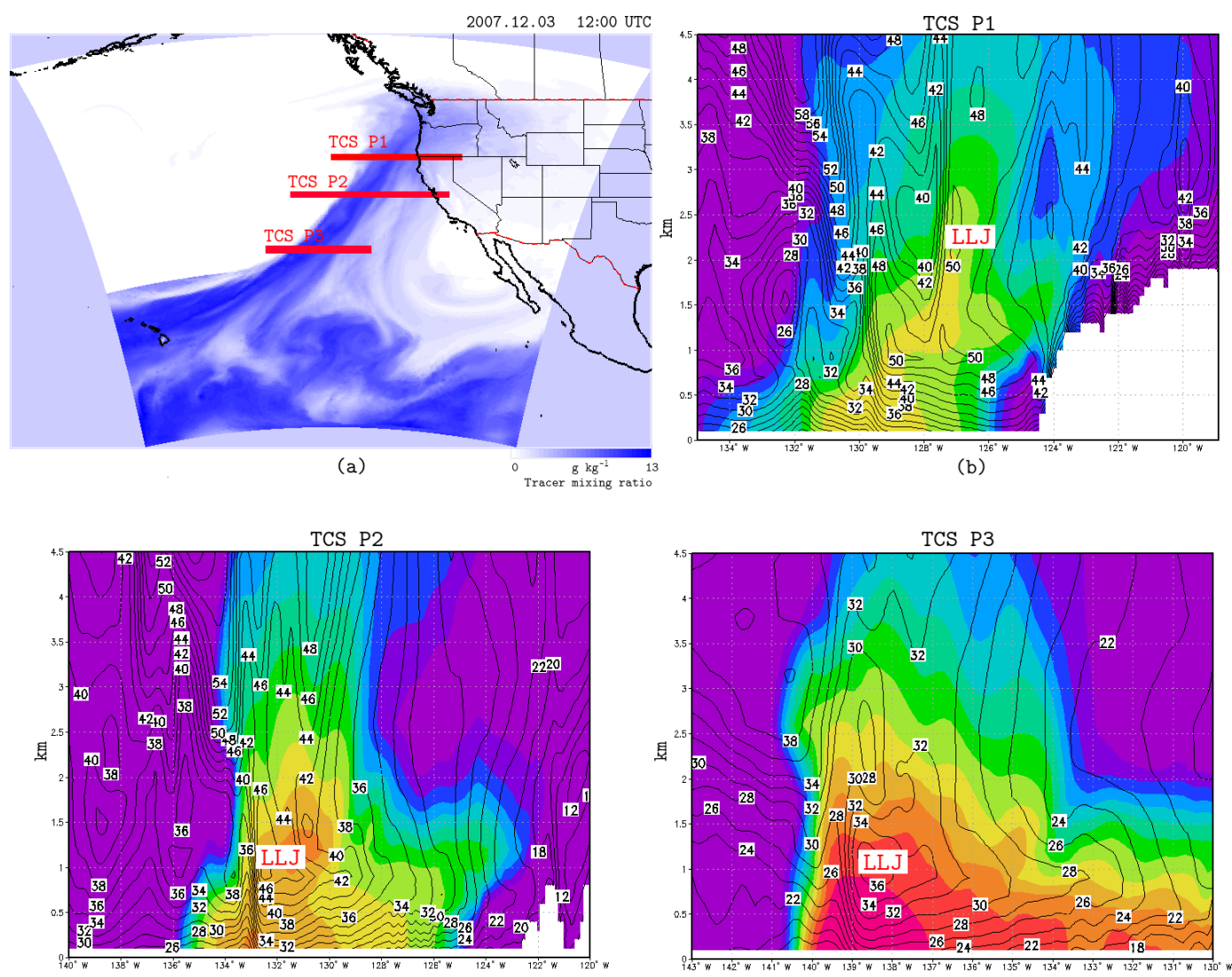

(c)

$\mathrm{g} \mathrm{kg}^{-1}$

(d)

Figure 8. Transversal cross sections along the central axis of the atmospheric river at latitudes 42.0 (transversal cross section P1), 37.4 (transversal cross section P2) and 30.6 (transversal cross section P3). The plots show the tracers' water vapor mixing ratio in grams per kilogram together with the wind module in meters per second. The estimated position of the LLJ is shown in the figures as well.

well defined case from the perspective of vertically integrated quantities such as IVT and IWV.

An analogous plot for the Atlantic case is presented in Appendix A (Fig. A2). The results are similar to the Pacific case, with no clear one-to-one connection between the LLJ and the maximum in tropical humidity. We note that no general conclusion can be obtained from particular case studies, but these results suggest that the perception that ARs are clearly associated with the LLJ of extratropical cyclones should be reviewed.

Figure 9a shows the area-averaged total precipitation (black circles) and the ratio between tracer precipitation and total precipitation (red crosses) throughout the region highlighted in Fig. 9b for the Pacific event. As expected, the plot shows that the maximum in tropical precipitation is observed during the landfall of the cold front and the AR, which closely coincides with the maximum in total precipitation. The secondary maximum in the total precipitation observed 1 day before the landfall of the AR event is due to the landfall of the warm front associated with the cyclone (see Fig. A3).
The convergence of local moisture would be the dynamical source for precipitation in the warm front.

\section{Conclusions}

A new 3-D Eulerian forward water vapor tracer tool implemented in the WRF model has been used to analyze two important AR events. The first event developed over the Pacific Ocean and corresponds to the Great Coastal Gale of 2007 on the US Pacific West Coast, which resulted in an estimated USD 678 million in direct economic damages (Dominguez et al., 2017). The Atlantic event corresponds to an atmospheric river event in October 1987 that resulted in record winds of $100 \mathrm{~km} \mathrm{~h}^{-1}$ and daily precipitation of over $100 \mathrm{~mm} \mathrm{day}^{-1}$ in Galicia (in the northwest of Spain) and Portugal. In an effort to understand the origin of moisture for these two AR events, we use 3-D water vapor tracers to quantify the percentage of total precipitable water and precipitation that originates from the tropics.

Results show that most of the moisture within and surrounding the two atmospheric rivers had its origin in the trop- 


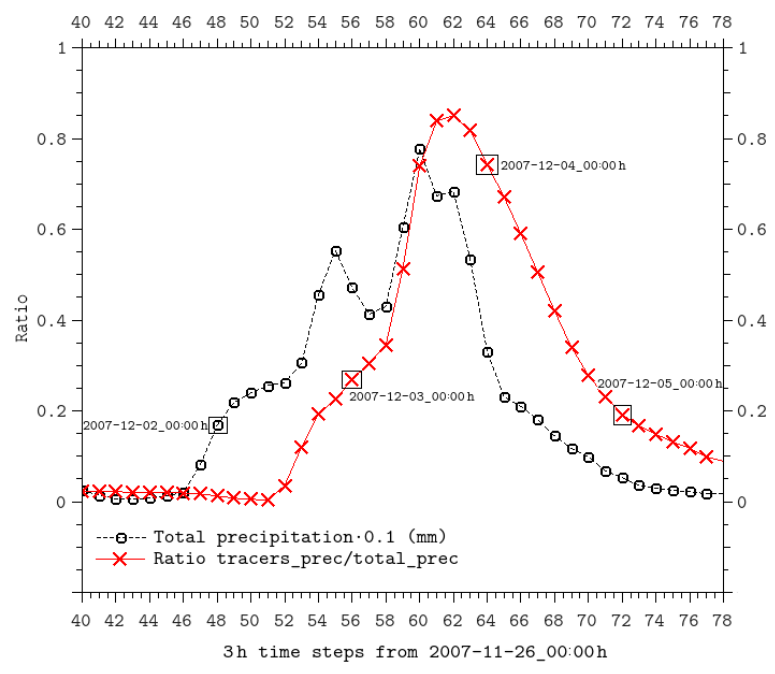

(a)

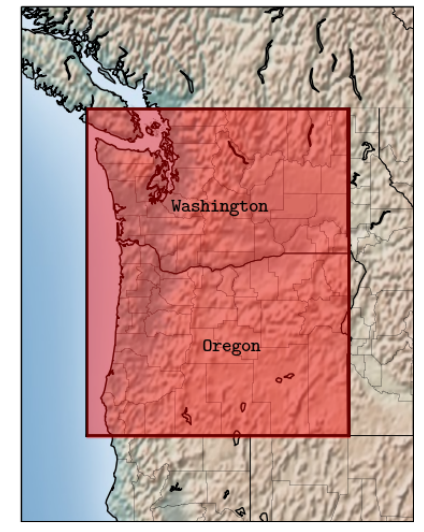

(b)

Figure 9. Evolution over time of the tropical precipitation (red crosses) and total precipitation (black circles) during the Pacific event (a). Data represent the spatial integration of both variables through the region highlighted in red in (b).

ical regions that we labeled with the 3-D tracer mask. Consequently, most of the precipitation that fell during these two events was composed of condensed tropical water vapor. The Pacific event shows a more intense connection with tropical regions than the Atlantic case. As a result, the percentage of tropical precipitation for this event over North America is higher and peaks around $85 \%$. Nevertheless, for the Atlantic event, still more than $60 \%$ of the resulting precipitation is of tropical origin.

The two selected case studies have been chosen due to the associated severity of flooding and socioeconomic damages. Both correspond to a strong AR feeding the system of a very intense extratropical storm. The conclusions drawn from these two AR events are thus not necessarily representative of the bulk of Pacific or Atlantic AR events. However, the results highlight the importance of tropical moisture for the two case studies. We also find evidence that convergence of local moisture also contributes to total precipitable water, especially in the post-frontal region, the leading edge of the $\mathrm{AR}$ and in the far northern latitudes where the tropical link has weakened. It is well known that in a mature system, when baroclinic structures are well differentiated, the stored water vapor tends to be constant (e.g., Bullock and Johnson, 1971), and since the fate of tropical moisture is to precipitate, local convergence should keep the balance by lateral inflow.

Based on these results, we hypothesize that the highest amounts of precipitable water can only be attained in a system in which a clear tropical source of moisture is sustained until landfall. Strong ARs with a direct link to tropical latitudes should be expected to result in more precipitation than those with local convergence as a primary feeding mechanism. It is our aim for the future to extend this work by including more cases.
Finally, our findings suggest that the maximum of tropical moisture does not necessarily coincide with the LLJ of either extratropical cyclone analyzed. Instead, this maximum is located near surface levels at lower latitudes to gradually ascend in northern latitudes, but still remaining below $2 \mathrm{~km}$, mostly within the boundary layer, in contrast with findings in other studies (Dacre et al., 2014). The maximum of tropical moisture may be situated below and toward the back, or ahead of the LLJ, which is located along the cold front. Both events are clear examples of ARs from the point of view of vertically integrated variables, such as IWV and IVT used in most detection algorithms; however, the vertical distribution of moisture of tropical origin reflects the complex processes leading to precipitation. The new 3-D tracer tool will allow us to delve into these processes and explore the role of tropical moisture exports in the initiation and intensification of AR events.

Data availability. No public data are derived from this research. For further information on the WRF tracer tool, please contact the corresponding author. 


\section{Appendix A: Supplementary figures}

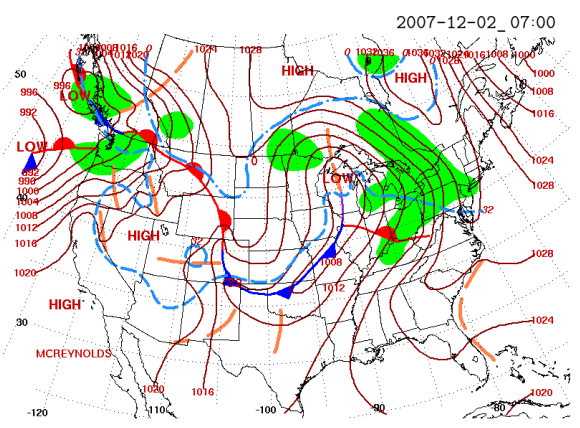

(a)

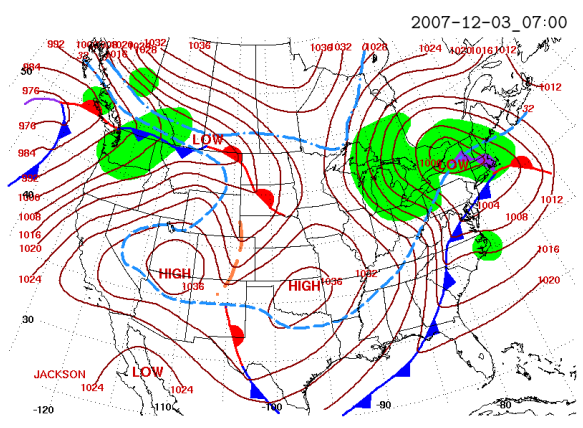

(b)

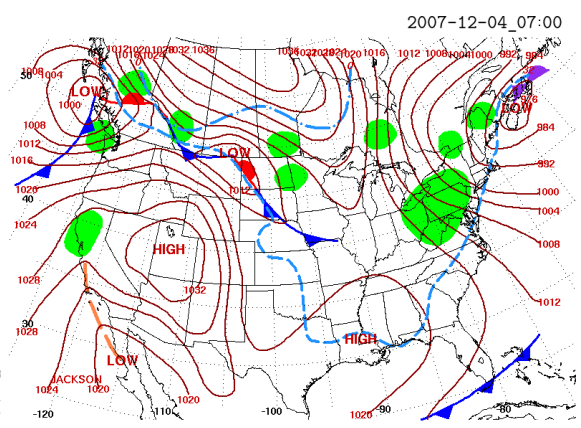

(c)

Figure A1. Front maps for the Pacific Great Coastal Gale of 2007 event.
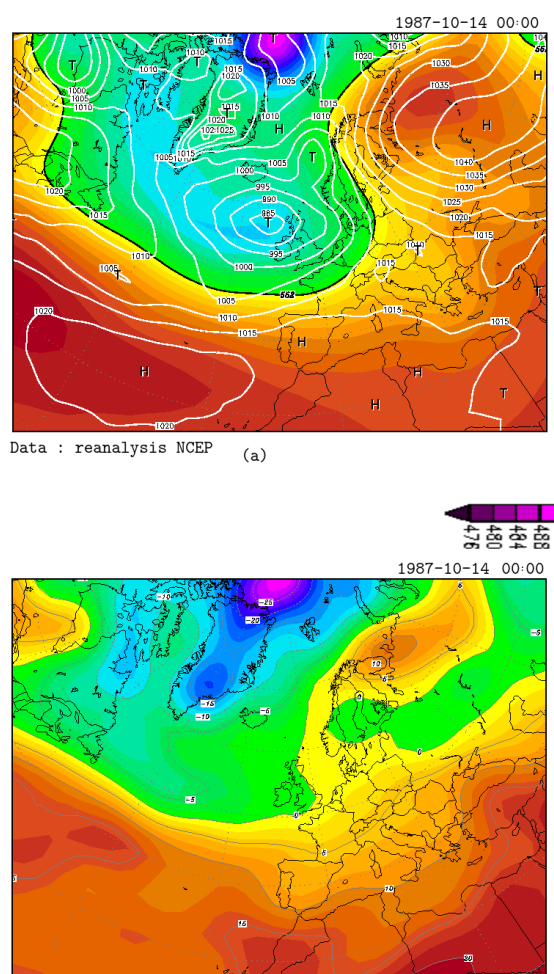

Data : reanalysis NCEP (d)

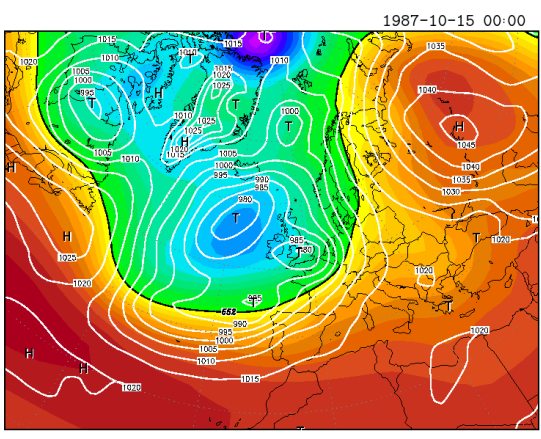

(b)

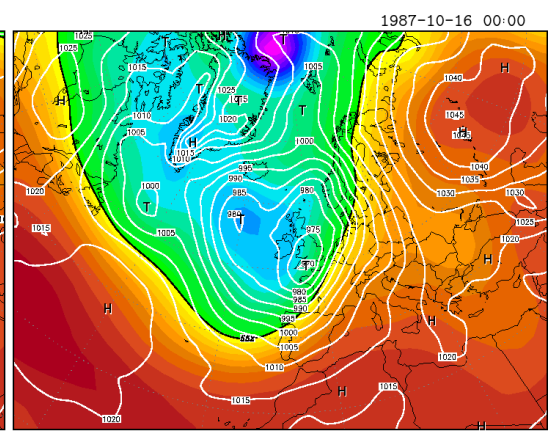

(c)

$500 \mathrm{hPa}$ geopotential

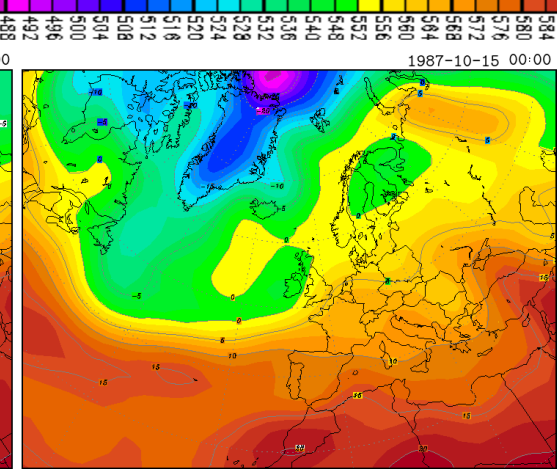

(e)

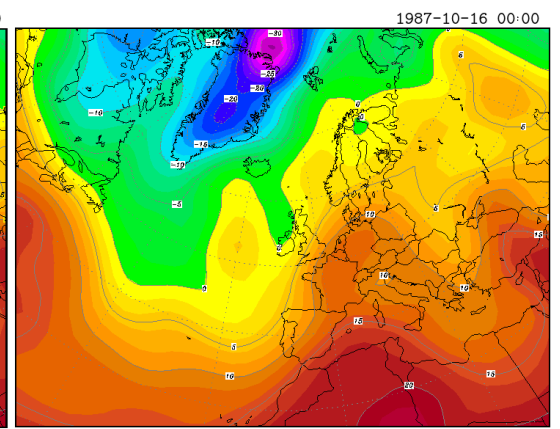

(f)

$850 \mathrm{hPa}$ temperature

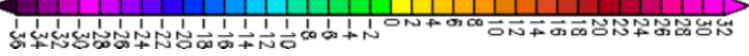

Figure A2. Showing the $500 \mathrm{hPa}$ geopotential field together with sea level pressure (a-c) and $850 \mathrm{hPa}$ temperature (d-f) in the Great Storm of 1987 event from 14 to 16 October. The figure highlights the cooperative linkage between a trough and low-level baroclinicity in the rapid development of the cyclonic system. 


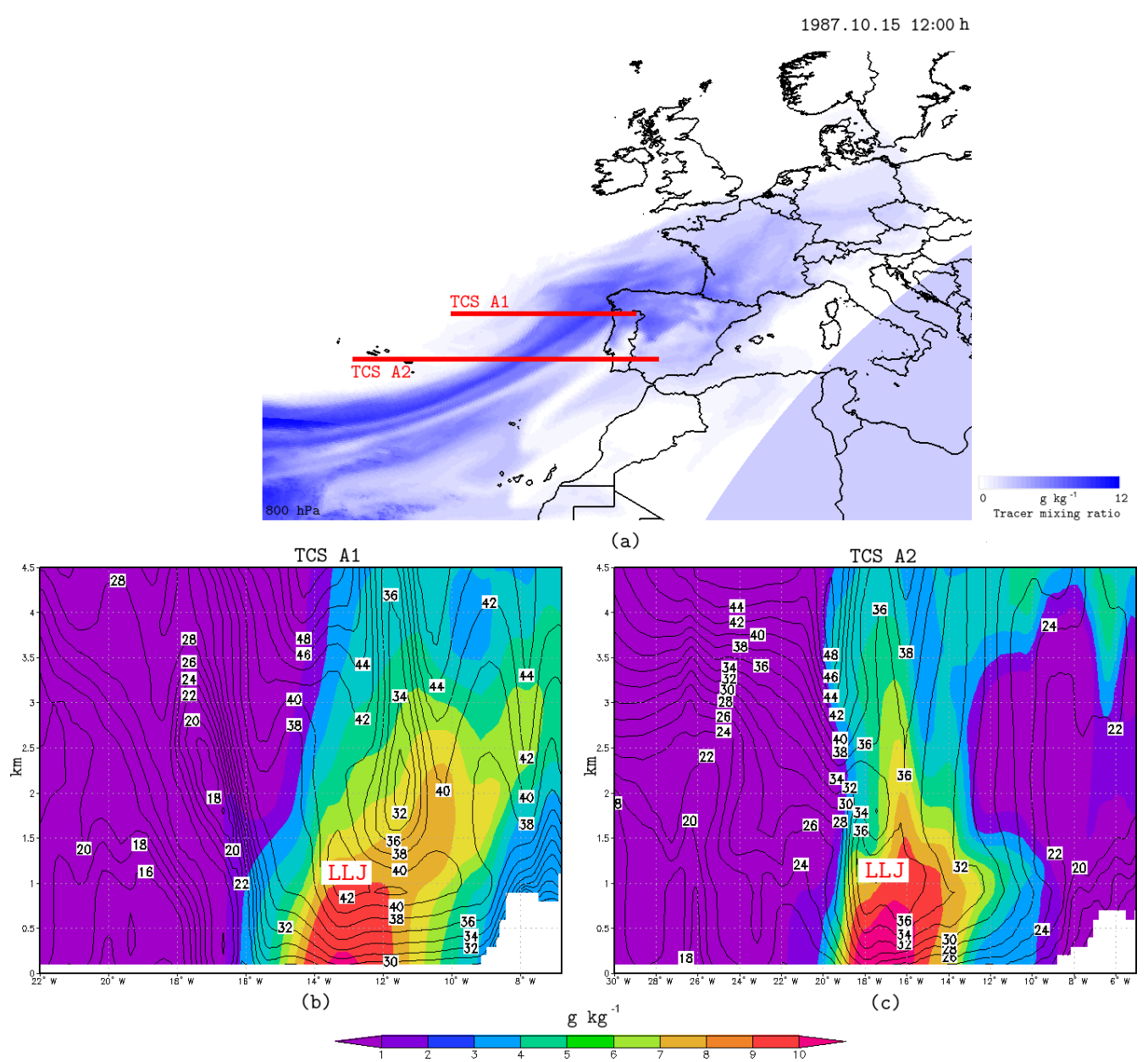

Figure A3. Same as Fig. 8 but for the Atlantic case. The corresponding latitudes are $41.8^{\circ}$ for transversal cross section A1 and $38.0^{\circ}$ for transversal cross section A2. 


\section{The Supplement related to this article is available online at https://doi.org/10.5194/esd-8-1247-2017-supplement.}

Competing interests. The authors declare that they have no conflict of interest.

Special issue statement. This article is part of the special issue "The 8th EGU Leonardo Conference: From evaporation to precipitation: the atmospheric moisture transport". It is a result of the 8th EGU Leonardo Conference, Ourense, Spain, 25-27 October 2016.

Acknowledgements. This work has been founded by the Ministerio de Economía y Competitivad (CGL2013-45932-R) from the Spanish Government and its mobility grants for pre-doc researchers. Jorge Eiras-Barca would like to express his gratitude to the Department of Atmospheric Sciences of the University of Illinois at Urbana-Champaign for the kind support in this project. Funding for Dominguez and $\mathrm{Hu}$ comes from NASA grant NNX14AD77G.

Edited by: Diego G. Miralles

Reviewed by: Brianna Pagán, Ruud van der Ent, and Lan Wang-Erlandsson

\section{References}

Arnault, J., Knoche, R., Wei, J., and Kunstmann, H.: Evaporation tagging and atmospheric water budget analysis with WRF: A regional precipitation recycling study for West Africa, Water Resour. Res., 52, 1544-1567, https://doi.org/10.1002/2015WR017704, 2016.

Avelino, A. and Dall'erba, S.: Comparing the economic impact of natural disasters generated by different input-output models. An application to the 2007 Chehalis River Flood (WA), North American Regional Science Conference, Minneapolis, 2016.

Bao, J.-W., Michelson, S. A., Neiman, P. J., Ralph, F. M., and Wilczak, J. M.: Interpretation of Enhanced Integrated Water Vapor Bands Associated with Extratropical Cyclones: Their Formation and Connection to Tropical Moisture, Mon. Weather Rev., 134, 1063-1080, https://doi.org/10.1175/MWR3123.1, 2006.

Belo-Pereira, M., Dutra, E., and Viterbo, P.: Evaluation of global precipitation data sets over the Iberian Peninsula, J. Geophys. Res., 116, D20101, https://doi.org/10.1029/2010JD015481, 2011.

Brands, S., Gutiérrez, J., and San-Martín, D.: Twentieth-century atmospheric river activity along the west coasts of Europe and North America: algorithm formulation, reanalysis uncertainty and links to atmospheric circulation patterns, Clim. Dynam., 48, 2771-2795, 2016.

Buckley, M. W. and Marshall, J.: Observations, inferences, and mechanisms of the Atlantic Meridional Overturning Circulation: A review, Rev. Geophys., 54, 5-63, 2016.

Buishand, T.: Some remarks on the use of daily rainfall models, J. Hydrol., 36, 295-308, 1978.
Bullock, B. R. and Johnson, D. R.: The generation of available potential energy by latent heat release in a mid-latitude cyclone, Mon. Weather Rev., 99, 1-14, 1971.

Burt, S. and Mansfield, A.: The Great Storm of 15-16 October 1987, Weather, 43, 90-110, 1988.

Cordeira, J. M., Ralph, F. M., and Moore, B. J.: The development and evolution of two atmospheric rivers in proximity to western North Pacific tropical cyclones in October 2010, Mon. Weather Rev., 141, 4234-4255, 2013.

Crout, R. L., Sears, I. T., and Locke, L. K.: The Great Coastal Gale of 2007 from Coastal Storms Program Buoy 46089, OCEANS 2008, Quebec City, QC, 1-7, https://doi.org/10.1109/OCEANS.2008.5152026, 2008.

Dacre, H. F., Clark, P. A., Martinez-Alvarado, O., Stringer, M. A., and Lavers, D. A.: How do atmospheric rivers form?, B. Am Meteorol. Soc., 96, 1243-1255, 2014.

Dettinger, M.: Climate Change, Atmospheric Rivers, and Floods in California - A Multimodel Analysis of Storm Frequency and Magnitude Changes, J. Am. Water Resour. As., 47, 514-523, https://doi.org/10.1111/j.1752-1688.2011.00546.x, 2011.

Dettinger, M., Ralph, F. M., and Lavers, D.: Setting the stage for a global science of atmospheric rivers, Eos, 96,https://doi.org/10.1029/2015EO038675, 2015.

Dettinger, M. D., Ralph, F. M., Das, T., Neiman, P. J., and Cayan, D. R.: Atmospheric Rivers, Floods and the Water Resources of California, Water, 3, 445-478, https://doi.org/10.3390/w3020445, 2011.

Dominguez, F., Miguez-Macho, G., and Hu, H.: WRF with Water Vapor Tracers: A Study of Moisture Sources for the North American Monsoon, J. Hydrometeorol., 17, 1915-1927, 2016.

Dominguez, F., Dall'erba, S., Huang, S., Avelino, A., Mehran, A., Hu, H., Schmidt, A., Schick, L., and Lettenmaier, D.: Tracking an Atmospheric River in a Warmer Climate: from Water Vapor to Economic Impacts, Earth Syst. Dynam. Discuss., https://doi.org/10.5194/esd-2017-64, in review, 2017.

Dudhia, J.: Numerical study of convection observed during the winter monsoon experiment using a mesoscale two-dimensional model, J. Atmos. Sci., 46, 3077-3107, 1989.

Eiras-Barca, J., Brands, S., and Miguez-Macho, G.: Seasonal variations in North Atlantic atmospheric river activity and associations with anomalous precipitation over the Iberian Atlantic Margin, J. Geophys. Res.-Atmos., 121, 931-948, 2016.

Gimeno, L., Dominguez, F., Nieto, R., Trigo, R., Drumond, A., Reason, C. J., Taschetto, A. S., Ramos, A. M., Kumar, R., and Marengo, J.: Major mechanisms of atmospheric moisture transport and their role in extreme precipitation events, Annu. Rev. Env. Resour., 41, 117-141, 2016.

Gómez, B. and Miguez-Macho, G.: The impact of wave number selection and spin up time when using spectral nudging for dynamical downscaling applications, Geophys. Res. Abstr., EGU201718466, EGU General Assembly 2017, Vienna, Austria, 2017.

Guan, B. and Waliser, D. E.: Detection of atmospheric rivers: Evaluation and application of an algorithm for global studies, J. Geophys. Res.-Atmos., 120, 12514-12535, 2015.

Herrera, S., Gutiérrez, J. M., Ancell, R., Pons, M. R., Frías, M. D., and Fernández, J.: Development and analysis of a 50-year high-resolution daily gridded precipitation dataset over Spain (Spain02), Int. J. Climatol., 32, 74-85, https://doi.org/10.1002/joc.2256, 2012. 
Higgins, R., Schemm, J., Shi, W., and Leetmaa, A.: Extreme precipitation events in the western United States related to tropical forcing, journal of climate, $13, \quad 793-820, \quad$ https://doi.org/10.1175/15200442(2000)013<0793:EPEITW>2.0.CO;2, 2000.

Hong, S.-Y. and Lim, J.-O. J.: The WRF single-moment 6-class microphysics scheme (WSM6), J. Korean Meteor. Soc., 42, 129151, 2006.

Hong, S.-Y., Noh, Y., and Dudhia, J.: A new vertical diffusion package with an explicit treatment of entrainment processes, Mon. Weather Rev., 134, 2318-2341, 2006.

Hoskins, B. and Berrisford, P.: A potential vorticity perspective of the storm of 15-16 October 1987, Weather, 43, 122-129, 1988.

$\mathrm{Hu}$, X.-M., Nielsen-Gammon, J. W., and Zhang, F.: Evaluation of three planetary boundary layer schemes in the WRF model, J. Appl. Meteorol. Clim., 49, 1831-1844, 2010.

Hu, X.-M., Klein, P. M., and Xue, M.: Evaluation of the updated YSU planetary boundary layer scheme within WRF for wind resource and air quality assessments, J. Geophys. Res.-Atmos., 118, 10490-10505 https://doi.org/10.1002/jgrd.50823, 2013.

Insua-Costa, D. and Miguez-Macho, G.: A new moisture tagging capability in the Weather Research and Forecasting Model: formulation, validation and application to the 2014 Great Lake-effect snowstorm, Earth Syst. Dynam. Discuss., https://doi.org/10.5194/esd-2017-80, in review, 2017.

Kain, J. S.: The Kain-Fritsch convective parameterization: an update, J. Appl. Meteorol., 43, 170-181, 2004.

Kim, J., Waliser, D., Neiman, P., Guan, B., Ryoo, J.-M., and Wick, G.: Effects of atmospheric river landfalls on the cold season precipitation in California, Clim. Dynam., 40, 465-474, https://doi.org/10.1007/s00382-012-1322-3, 2013.

Knippertz, P. and Wernli, H.: A Lagrangian climatology of tropical moisture exports to the Northern Hemispheric extratropics, J. Climate, 23, 987-1003, 2010.

Knippertz, P., Wernli, H., and Gläser, G.: A global climatology of tropical moisture exports, J. Climate, 26, 3031-3045, 2013.

Lavers, D. A. and Villarini, G.: The nexus between atmospheric rivers and extreme precipitation across Europe, Geophys. Res. Lett., 40, 3259-3264, https://doi.org/10.1002/grl.50636, 2013.

Lavers, D. A. and Villarini, G.: The relationship between daily European precipitation and measures of atmospheric water vapour transport, Int. J. Climatol., 35, 2187-2192, https://doi.org/10.1002/joc.4119, 2014.

Lavers, D. A., Allan, R. P., Wood, E. F., Villarini, G., Brayshaw, D. J., and Wade, A. J.: Winter floods in Britain are connected to atmospheric rivers, Geophys. Res. Lett., 38, L23803, https://doi.org/10.1029/2011GL049783, 2011.

Lavers, D. A., Villarini, G., Allan, R. P., Wood, E. F., and Wade, A. J.: The detection of atmospheric rivers in atmospheric reanalyses and their links to British winter floods and the large-scale climatic circulation, J. Geophys. Res.-Atmos., 117, D20106, https://doi.org/10.1029/2012JD018027, 2012.

Lavers, D. A., Allan, R. P., Villarini, G., Lloyd-Hughes, B., Brayshaw, D. J., and Wade, A. J.: Future changes in atmospheric rivers and their implications for winter flooding in Britain, Environ. Res. Lett., 8, 034010, https://doi.org/10.1088/17489326/8/3/034010, 2013.

Leung, L. R. and Qian, Y.: Atmospheric rivers induced heavy precipitation and flooding in the western U.S. simulated by the
WRF regional climate model, Geophys. Res. Lett., 36, L03820, https://doi.org/10.1029/2008GL036445, 2009.

Livneh, B., Bohn, T. J., Pierce, D. W., Munoz-Arriola, F., Nijssen, B., Vose, R., Cayan, D. R., and Brekke, L.: A spatially comprehensive, hydrometeorological data set for Mexico, the US, and Southern Canada 1950-2013, Scientific data, 2, 2015.

Mahoney, K., Jackson, D. L., Neiman, P., Hughes, M., Darby, L., Wick, G., White, A., Sukovich, E., and Cifelli, R.: Understanding the role of atmospheric rivers in heavy precipitation in the southeast United States, Mon. Weather Rev., 144, 1617-1632, 2016.

Maraun, D., Wetterhall, F., Ireson, A. M., Chandler, R. E., Kendon, E. J., Widmann, M., Brienen, S., Rust, H. W., Sauter, T., Themeß1, M., Venema, V. K. C., Chun, K. P., Goodess, C. M., Jones, R. G., Onof, C., Vrac, M., and Thiele-Eich, I.: Precipitation downscaling under climate change: Recent developments to bridge the gap between dynamical models and the end user, Rev. Geophys., 48, RG3003, https://doi.org/10.1029/2009RG000314, 2010.

Michalakes, J., Dudhia, J., Gill, D., Henderson, T., Klemp, J., Skamarock, W., and Wang, W.: The weather research and forecast model: software architecture and performance, in: Proceedings of the Eleventh ECMWF Workshop on the Use of High Performance Computing in Meteorology, 156-168, World Scientific: Singapore, 2005.

Miguez-Macho, G., Stenchikov, G. L., and Robock, A.: Spectral nudging to eliminate the effects of domain position and geometry in regional climate model simulations, J. Geophys. Res.-Atmos., 109, D13104, https://doi.org/10.1029/2003JD004495, 2004.

Miguez-Macho, G., Stenchikov, G. L., and Robock, A.: Regional climate simulations over North America: Interaction of local processes with improved large-scale flow, J. Climate, 18, 12271246, 2005.

Miguez-Macho, G., Rios-Entenza, A., and Dominguez, F.: Regional climate simulations with moisture tracers to investigate landatmosphere interactions in the terrestrial water cycle over the Iberian Peninsula, Geophys. Res. Abstr., EGU2013-12677, EGU General Assembly 2013, Vienna, Austria, 2013.

Mlawer, E. J., Taubman, S. J., Brown, P. D., Iacono, M. J., and Clough, S. A.: Radiative transfer for inhomogeneous atmospheres: RRTM, a validated correlated-k model for the longwave, J. Geophys. Res.-Atmos., 102, 16663-16682, 1997.

Mundhenk, B. D., Barnes, E. A., Maloney, E. D., and Nardi, K. M.: Modulation of atmospheric rivers near Alaska and the US West Coast by northeast Pacific height anomalies, J. Geophys. Res.-Atmos., 121, 12751-12765, https://doi.org/10.1002/2016JD025350, 2016.

Nayak, M. A., Villarini, G., and Lavers, D. A.: On the skill of numerical weather prediction models to forecast atmospheric rivers over the central United States, Geophys. Res. Lett., 41, 4354 4362, 2014.

Neiman, P. J., Ralph, F. M., Wick, G. A., Kuo, Y.-H., Wee, T.-K., Ma, Z., Taylor, G. H., and Dettinger, M. D.: Diagnosis of an Intense Atmospheric River Impacting the Pacific Northwest: Storm Summary and Offshore Vertical Structure Observed with COSMIC Satellite Retrievals, Mon. Weather Rev., 136, 4398-4420, 2008a.

Neiman, P. J., Ralph, F. M., Wick, G. A., Lundquist, J. D., and Dettinger, M. D.: Meteorological Characteristics and Over- 
land Precipitation Impacts of Atmospheric Rivers Affecting the West Coast of North America Based on Eight Years of SSM/I Satellite Observations, J. Hydrometeorol., 9, 22-47, https://doi.org/10.1175/2007JHM855.1, 2008b.

NOAA (National Oceanic and Atmosphere Administration): Pacific Northwest Storms of December, U.S. DEPARTMENT OF COMMERCE National Oceanic and Atmospheric Administration National Weather Service Silver Spring, Maryland, 1-3, 2008.

Payne, A. E. and Magnusdottir, G.: An evaluation of atmospheric rivers over the North Pacific in CMIP5 and their response to warming under RCP 8.5, J. Geophys. Res.-Atmos., 120, 1117311190, https://doi.org/10.1002/2015JD023586, 2015.

Ralph, F. M. and Dettinger, M. D.: Storms, floods, and the science of atmospheric rivers, Eos T. Am. Geophys. Un., 92, 265-266, https://doi.org/10.1029/2011EO320001, 2011.

Ralph, F. M., Neiman, P. J., and Wick, G. A.: Satellite and CALJET Aircraft Observations of Atmospheric Rivers over the Eastern North Pacific Ocean during the Winter of 1997/98, Mon. Weather Rev., 132, 1721-1745, https://doi.org/10.1175/15200493(2004)132<1721:SACAOO>2.0.CO;2, 2004.

Ralph, F. M., Neiman, P. J., and Rotunno, R.: Dropsonde Observations in Low-Level Jets over the Northeastern Pacific Ocean from CALJET-1998 and PACJET-2001: Mean Vertical-Profile and Atmospheric-River Characteristics, Mon. Weather Rev., 133, 889-910, https://doi.org/10.1175/MWR2896.1, 2005.

Ralph, F. M., Neiman, P. J., Wick, G. A., Gutman, S. I., Dettinger, M. D., Cayan, D. R., and White, A. B.: Flooding on California's Russian River: Role of atmospheric rivers, Geophys. Res. Lett., 33, L13801, https://doi.org/10.1029/2006GL026689, 2006.

Ralph, F. M., Coleman, T., Neiman, P. J., Zamora, R. J., and Dettinger, M. D.: Observed Impacts of Duration and Seasonality of Atmospheric-River Landfalls on Soil Moisture and Runoff in Coastal Northern California, J. Hydrometeorol., 14, 443-459, https://doi.org/10.1175/JHM-D-12-076.1, 2013.

Ramos, A. M., Trigo, R. M., Liberato, M. L. R., and Tomé, R.: Daily precipitation extreme events in the Iberian Peninsula and its association with Atmospheric Rivers, J. Hydrometeorol., 16, 579-597, https://doi.org/10.1175/JHM-D-14-0103.1, 2015.

Ramos, A. M., Nieto, R., Tomé, R., Gimeno, L., Trigo, R. M., Liberato, M. L. R., and Lavers, D. A.: Atmospheric rivers moisture sources from a Lagrangian perspective, Earth Syst. Dynam., 7, 371-384, https://doi.org/10.5194/esd-7-371-2016, 2016.

Rienecker, M. M., Suarez, M. J., Gelaro, R., Todling, R., Bacmeister, J., Liu, E., Bosilovich, M. G., Schubert, S. D., Takacs, L., Kim, G., Bloom, S., Chen, J., Collins, D., Conaty, A., da Silva, A., Gu, W., Joiner, J., Koster, R. D., Lucchesi, R., Molod, A., Owens, T., Pawson, S., Pegion, P., Redder, C. R., Reichle, R., Robertson, F. R., Ruddick, A. G., Sienkiewicz, M., and Woollen, J.: MERRA: NASA's modern-era retrospective analysis for research and applications, J. Climate, 24, 3624-3648, https://doi.org/10.1175/JCLI-D-11-00015.1, 2011.
Rutz, J. J., Steenburgh, W. J., and Ralph, F. M.: Climatological Characteristics of Atmospheric Rivers and Their Inland Penetration over the Western United States, Mon. Weather Rev., 142, 905-921, https://doi.org/10.1175/MWR-D-13-00168.1, 2013.

Rutz, J. J., Steenburgh, W. J., and Ralph, F. M.: Climatological characteristics of atmospheric rivers and their inland penetration over the western United States, Mon. Weather Rev., 142, 905-921, 2014.

Ryoo, J.-M., Waliser, D. E., Waugh, D. W., Wong, S., Fetzer, E. J., and Fung, I.: Classification of atmospheric river events on the US West Coast using a trajectory model, J. Geophys. Res.-Atmos., 120, 3007-3028, 2015.

Shin, H. H. and Hong, S.-Y.: Intercomparison of planetary boundary-layer parametrizations in the WRF model for a single day from CASES-99, Bound.-Lay. Meteorol., 139, 261-281, 2011.

Shutts, G. J.: Dynamical aspects of the October storm, 1987: A study of a successful fine-mesh simulation, Q. J. Roy. Meteor. Soc, 116, 1315-1347, 1990.

Skamarock, W. C., Klemp, J. B., Dudhia, J., Gill, D. O., Barker, D. M., Wang, W., and Powers, J. G.: A description of the advanced research WRF version 2, Tech. rep., DTIC Document, 2005.

Sodemann, H. and Stohl, A.: Moisture Origin and Meridional Transport in Atmospheric Rivers and Their Association with Multiple Cyclones*, Mon. Weather Rev., 141, 2850-2868, https://doi.org/10.1175/MWR-D-12-00256.1, 2013.

Warner, M. D., Mass, C. F., and Salathé, E. P.: Wintertime Extreme Precipitation Events along the Pacific Northwest Coast: Climatology and Synoptic Evolution, Mon. Weather Rev., 140, 20212043, https://doi.org/10.1175/MWR-D-11-00197.1, 2012.

Warner, M. D., Mass, C. F., and Salathé, E. P.: Changes in Winter Atmospheric Rivers along the North American West Coast in CMIP5 Climate Models, J. Hydrometeorol., 16, 118-128, https://doi.org/10.1175/JHM-D-14-0080.1, 2014.

Zhu, Y. and Newell, R. E.: A Proposed Algorithm for Moisture Fluxes from Atmospheric Rivers, Mon. Weather Rev., 126, 725-735, https://doi.org/10.1175/15200493(1998)126<0725:APAFMF>2.0.CO;2, 1998. 